\title{
Ancient Anatolian Grids
}

\section{Şirin Gülcen EREN}

Süleyman Demirel University, Faculty of Architecture Department of City and Regional Planning, sirineren@sdu.edu.tr/gulcen8@hotmail.com

\begin{abstract}
For as long as humans have existed, they have created specific legal structures and technical means of representation in order to situate themselves within the geographical space where they live, to find the right direction, to measure time and distance, to define property and to calculate gradients. With the progress of civilisation, maps came to be used as an instrument for controlling society, siting architectural structures, establishing towns and determining trade axes and property rights. As social structures and the needs and relationships embedded in them changed, and technical and technological methods became more advanced, cartography developed too, and the uses of maps increased. From their earliest discovery, the basic characteristics of maps were grids, isohypses (contours) and physical data. The geography and settlements of Anatolia provide some clues as to the types of grid that were used in ancient times. There are invisible grids compatible with Euclidean geometry. These can only be detected from the clues given by the settlement locations. These grids, which have determined the locations of settlements, the pattern of roads, the geostamps ${ }^{\circledR}$ and the division of the land in Anatolia, are an unknown aspect of the ancient era.

In response to the obscurity of the topic, this paper sets out to make a preliminary appraisal of the grids of the ancient era. With the aid of a multi-disciplinary approach, an inter-disciplinary methodology and the Google Earth software, it outlines some of the types of grid that it has been possible to identify from analyses and drawings of the geography of Anatolia, together with their measures and origins. The paper aims to make a contribution to the disciplines of cartography and spatial planning by presenting the invisible grids of the Anatolia.
\end{abstract}

Keywords: Grid, Cartography, Spatial Planning, Anatolia.

\section{Introduction}

Humans have had a sense of property and ownership, and an instinct to prevent social disorder or to seek the right path, ever since they were created. The history of humanity shows that humans, living within communities, have maintained this way of life in accordance with certain rules that they have either determined or accepted. After adopting a settled way of life, humans also established rules and norms for determining the spaces where they were to live, shelter, feed and sow crops.

Thousands of years ago, just like today, property rights were set out through the use of legal structures and of technical practices and means of representation. Every legal decision is grounded in a certain technical and social infrastructure. In the determination of property rights, this infrastructure is nowadays provided by a knowledge of topography and by mapping and cadastre techniques using GIS.

Maps have been produced with a view to being able to measure distances, divide up the land, indicate the locations of people and their settlements, find the right direction and calculate areas, gradients and times (Memiş, 2016; Çalışkan, 2017). As the use of maps spread, new mapping methods and measurement systems were developed, in line with technical and technological progress in the science of cartography, for the purposes of measuring spaces, distances, locating geographical points and calculating the size of the earth. However, in spite of all these developments, the basic critical element in the mapping of any geographical space remained the same: the grid or system of coordinates and origins.

The use of the grid is a technical practice that is essential for specifying the legal situation in a permanent and comprehensible manner. It is a system that describes any place in the world as a topographical point and represents it by sets of numbers, letters and symbols (Üstün, 1996; Çalışkan 2017). Mathematics and geometry are the instrument of this standard system of measurement and location used to determine the limits of properties and ownership rights.

During studies of the cadastral regime in Anatolia in ancient times, making use of Google Earth, certain spatial information was obtained that serves to identify the grid system once in use. The elements of this system consist of a number of archaeological findings, the lines that exist on the land, and the locations of settlements. The types of grid that it was possible to identify from these elements as a result of approximately two years of study constitute the topic of the present paper.

The grid systems of the ancient era are unknown to the disciplines concerned with spatial studies. They are different from the systems of coordinates that modern humans use today and from the ways in which modern humans measure dimensions and determine the direction of north. The lack of field research on grids may be attributable to the fact that the grids of the ancient era are invisible. These qualities of the grids are factors that make them difficult to notice. As the existence of such grids is unknown, no enquiries have been made into their typologies either. There are also only limited studies of the spatial relations and networks among the settlements of the ancient era. The fact that knowledge of the grids of the ancient era was not passed on to later periods can be assumed to be attributable to the erosion and destruction which the societies, structures and settlements of this period underwent. 
In response to the obscurity of the topic described above, this paper sets out to establish the existence of the grid systems found to have been created in the ancient area and to discuss the typologies, origins and characteristics of those grids which it has been possible to identify. As these grids shaped the pattern of settlements in the ancient era, the study also incorporates a proposed method for understanding spatial relations and networks. The grids are addressed from a multidisciplinary angle and an interdisciplinary methodology is employed. By proving the existence of the grids, it is intended to make a contribution to the fields of spatial planning, historical geography and cartography. In addition, the paper contains some propositions regarding the dating of the grids.

The research, which was done by the researcher using her own means, constitutes a preliminary appraisal of the grids. In order to read the grid systems, it was necessary to reduce the observations made of the earth's surface using the Google Earth software to a system of references and to query these on the basis of units of measurement used in ancient times.

The paper begins by describing the geography of Anatolia and its ancient grid systems. Secondly, it discusses the types and characteristics of the grids which has been possible to identify. In the conclusion, an assessment is made of the relationship between the grids and the coordinate systems and human settlements of the ancient era and the present.

While the reasons or justifications for which civilisations establish grid systems and grid dates are not the topic of the paper. However, those that have been identified are mentioned as a guide for future researches. The relationships of the grids to the system of coordinates used today or to the civilisations which created them require more advanced study. These relations are only evaluated in this paper in general terms.

\section{The geography of Anatolia and its ancient grid systems}

Today's system of coordinates has its origin in Greenwich and is represented by invisible (imaginary) grids made up of lines of longitude (meridians) and lines of latitude (parallels). According to this system and its origin, Anatolia is geographically located between the $26^{\text {th }}$ and $45^{\text {th }}$ meridians East and between the $36^{\text {th }}$ and $42^{\text {nd }}$ parallels North. Anatolia stretches 1,565 kilometres from West to East and 680 kilometres from North to South. The average altitude is 1,132 metres and it is surrounded by seas on three sides. The climate and lie of the land provide for a wide variety of plants and crops. Indeed, Anatolia is situated at the point where the regions where the earliest experiences with agriculture were acquired namely, the Golden Triangle (Schmidt, 2014) and the Fertile Crescent (Childe, 1971; Childe 1974; Mark, 2018) - coincide.

Up until a few decades ago, the Cartesian system of coordinates was used as the system for mapping Anatolia (Şerbetçi, 1999).
The geographical characteristics of Anatolia have given it a special position in history. This geographical space has been settled by various civilisations at different times, or witnessed their passage or destruction. As a result, Anatolia is home to many historical mysteries.

In Anatolia, "invisible grids", making use of Euclidean geometry, which can be identified from the locations of settlements (Figure 1).

The grids drawn onto the surface using fractal geometry have been found to point in the direction that is accepted as North today. They take as their origin a fixed location nearby. The grid systems formed later using Euclidean geometry pass through the settlements, and each has a different origin and a different direction for North.

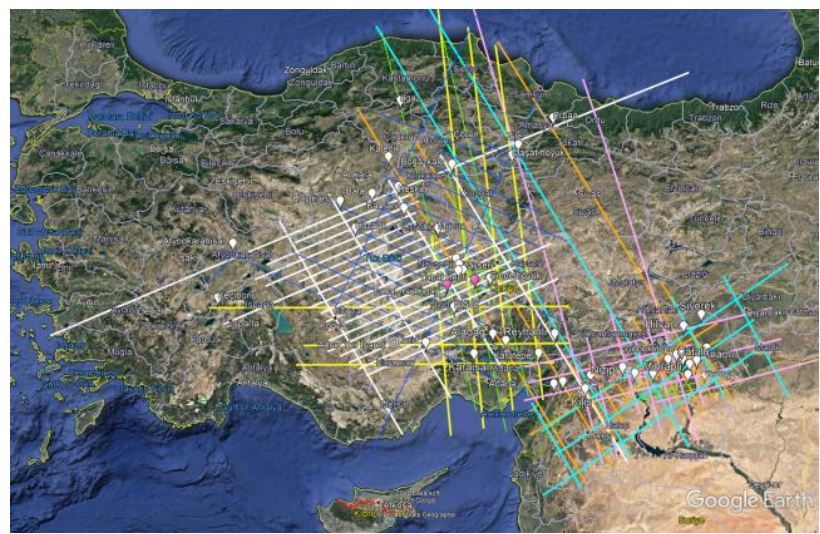

Figure 1. Grid Systems of Different Civilisations and their Overlap $\left(39^{\circ} 00^{\prime} 27.37^{\prime \prime N} 36^{\circ} 27^{\prime} 12.76 " \mathrm{E}\right)$ [Eye level $1,133,88 \mathrm{~km}$ ] Source: Author's Drawing (2018) over view from Google Earth 2013.

The limits of the areas to which the grids were applied is a matter for a separate study. As the measurements were made using Google Earth, there is still a need to locate the grids exactly and determine the intervals precisely by using GIS. In determining the grid typologies, no enquiry was made into their relationships with the diameter or circumference of the world.

\section{Types of Grid}

\subsection{First Grid - Grid A}

Eren (2018a) conducted an examination of three lined and marked lime stone plaques (Arimura et al, 2000; Özbaşaran and Molist, 2007:183; Özbaşaran 2008; Bozbay, 2009) from Akarçay Tepe and consequently determined that the plaques were related to the settlements of Birecik (Plaque A), Yeşilözen (Plaque B) and Nizip (Plaque C). Eren's (2018a) examination was based on a comparison between the current cadastral and settlement pattern corresponding to the measurements of and the designs on the plaques. The plaques were examined by superimposing the plaque plan on to the modern topography and urban pattern. These plaques were found to be hand-crafted products with the characteristics of a 10,689 year-old cadastral map and spatial plan depicted in the form of a three-dimensional landscape model with a scale of 1:1,000 (Eren, 2018a). 
The human settlements of the period when the plaques were made belonged to early-sedentary communities.

In the course of this analysis, Eren (2018a) noticed, based on the existence of a fourth Plaque, belonging to the settlement of Kelekli, for the examination of which permission was not granted, that the settlements of Kelekli, Birecik and Yeşilözen are situated along a straight line. Eren (2018a) remarks that this positioning along a line suggests a perception of lines of longitude, but that it is not possible to come to such an evaluation without examining the locations of all the plaques.

As these Plaques, numbering 295 in all (Bozbay, 2009), were found at Akarçay Tepe, they may be thought to have originated there. According to Eren (2018a), this must be the origin as there is a proportional relationship among the distances of the settlements from Akarçay Tepe: $13 \mathrm{~km}$ for Birecik, $23 \mathrm{~km}$ for Nizip, and $33 \mathrm{~km}$ for Yeşilözen as the crow flies.

These spatial references prove that basic knowledge and principles of geography, cartography and spatial planning were in use at the time when the plaques were made.

Eren (2018a) determined that the parallel lines commonly seen in the agricultural plots on the plaques were the result of an effort to divide the land into parcels that were almost standard, given the proportionality or equality apparent in their dimensions.

The use of a grid is thought to have been necessary for areas of agricultural land within a certain range of values varying from settlement to settlement depending on the gradient. For this reason, the plaque patterns were checked for grids, and a slanted grid system emerged made up of rectangles measuring $3.2 \mathrm{~cm}$ by $4.2 \mathrm{~cm}$ $\left(13.44 \mathrm{~cm}^{2}\right)$. The grid generated on the examined plaques terminates with the limits of the agricultural land. However, it has been determined that the same grid system can be applied in the other settlements on the plaques (Eren 2018a) (Figures 2-4).

Eren (2018a) states that the division of the grid indicated by the agricultural areas shown on the plaques could be related to the sizes of households. Since approximately $70 \%$ of the parcels had a surface area divisible by 9 , it could be concluded that the land to which a square with dimensions of $3 \mathrm{~m}$ by $3 \mathrm{~m}$ to measure surface was applied. It is thought that the cadastral systematic was arranged in such a way as to produce $9 \mathrm{~m}^{2}$ of land per person. Towers (2017) reports that the natives of Pueblo arrange their areas of settlement taking the measure of $30 \mathrm{~cm}$, the modern foot, as their common unit of length.

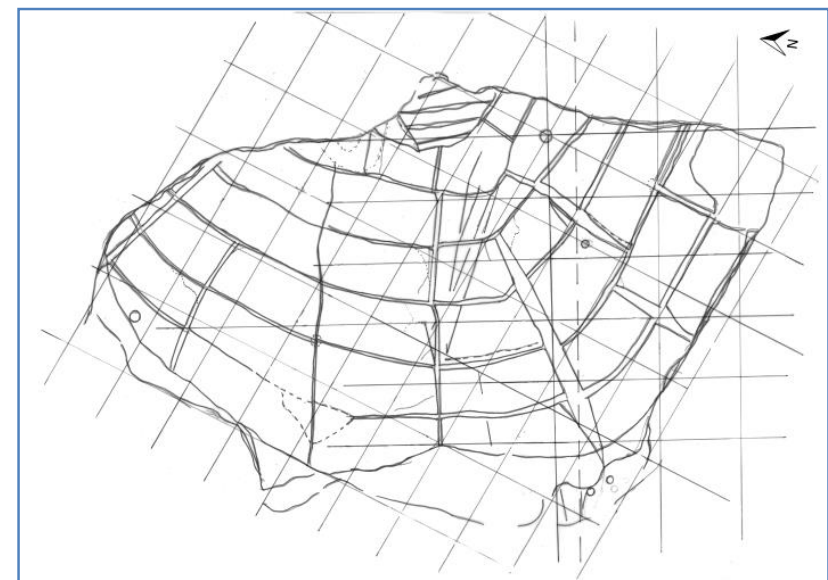

Figure 2. Plaque A (Birecik) Plan-Grid Superimposition.

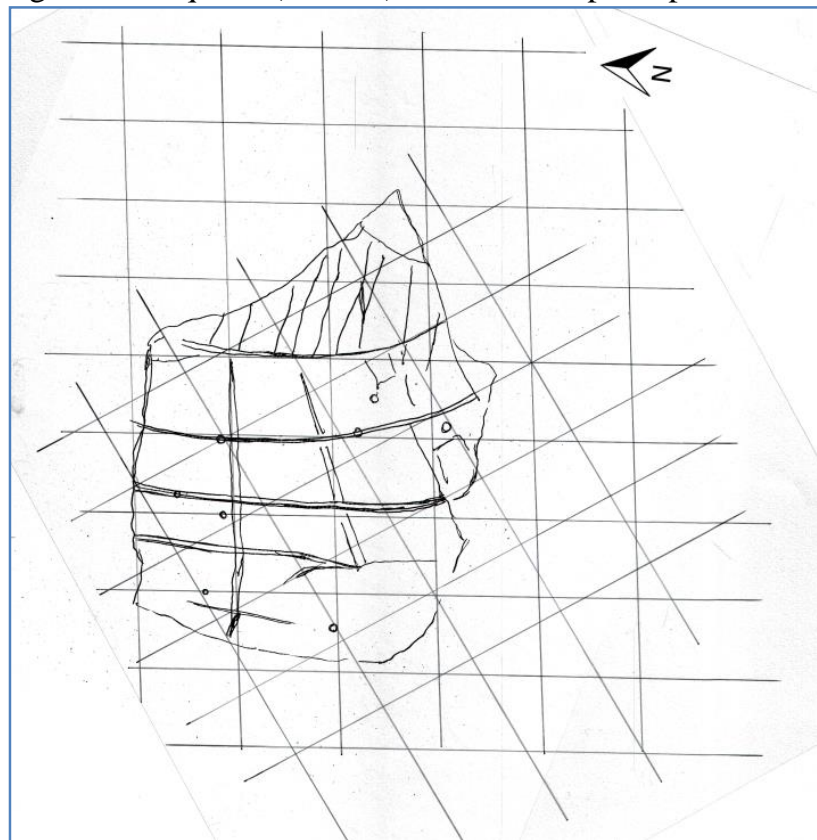

Figure 3. Plaque B (Yeşilözen) Plan-Grid Superimposition.

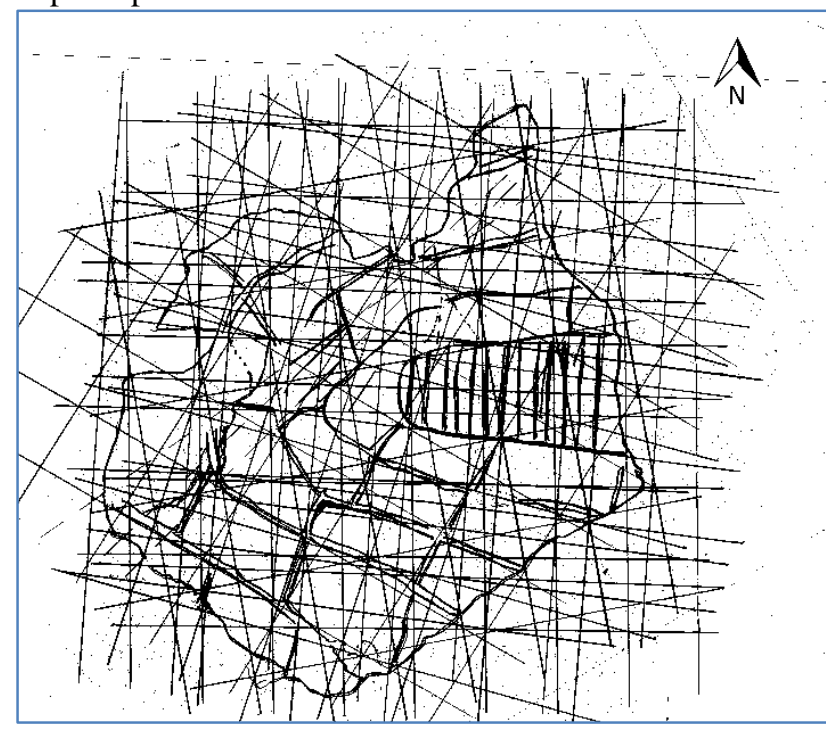

Figure 4. Plaque C (Nizip) Grid Plan-Grid Superimposition (Two south grids are unpresented due to lack of reference points). 
Clear short straight lines (slits) (Figure 5, Photograph 1) were found to have been made on the turns of the curves (isohypses on the land) corresponding to the upper parts of the land (higher parts of the models). These lines are incomplete. There are also neat circular hollows (holes) (Photograph 1). The lines and holes are thought to represent support systems essential for the development of the fixed ecological and social conditions which the agricultural community needed for certain groups of crops. Moreover, the plaques applied the systematics of triangulation used in mapping with the locations of water wells (Figure 5a).By drawing lines parallel to those that are formed by extending the short straight lines on the plaques, and grid is redrawn parallel to these lines, another system was discovered that rotates the existing grid in a different direction (Eren 2018a) (Figure 5b).
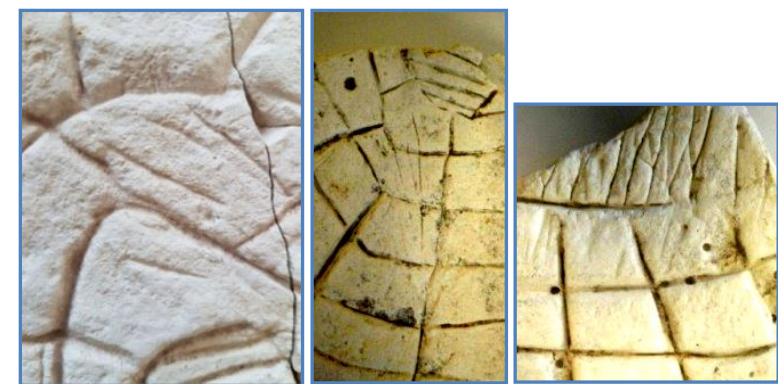

Photograph 1. a.b.c. Examples of Miniature Lines (Slits) and Holes. Photographed by the Author, 2017.
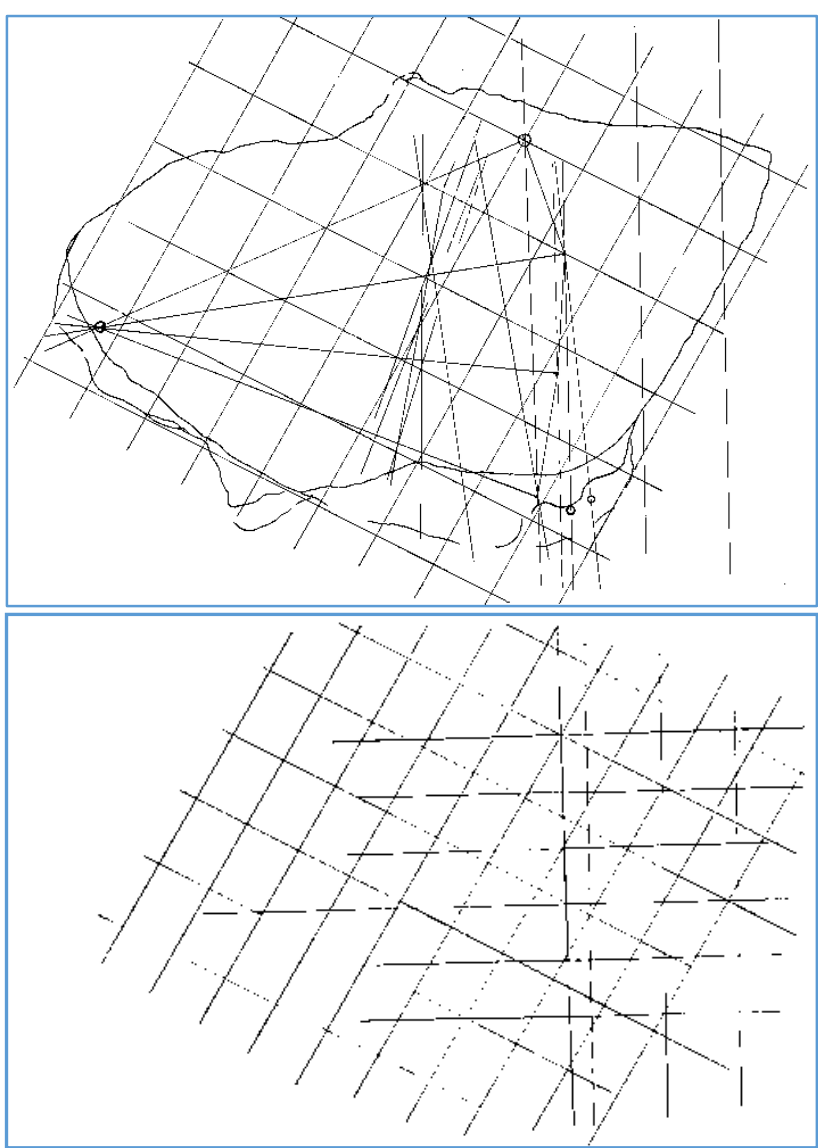

Figure 5. Plaque A (Birecik) (Eren, 2018a).

a. Systematics of Triangulation and Ring b. Systematics of Grid Rotation and the Ring.
The way in which the grid is rotated makes it possible to measure and divide land lying on an isohypse at a given altitude in varying directions correctly. This systematic is thought to have been designed with the aim of parcelling out the land within a small area at the height of the same isohypse and creating a division using a specific coefficient. For English (1968), the underground-tunnel wells (qanats) in the south of Kirman, Iran are linked in rings, and that this is a practice used in a dry, upland basin. The ring relationship on Plaque A can be seen in Figure 5a.

\subsection{Invisible (imaginary) grids}

Invisible (imaginary) grids may be described as broad geographical grids or flat earth grids. They were drawn using Euclidean geometry (squares or rectangle forms) in a manner similar to the coordinate systems in use today. These grids are oriented towards a certain pole and an origin. The existence in the land equation of right-angled systems and large axis lines indicates that the grids were determinant factors in the locations of settlements. In other words, the settlements are either located on the grid lines or at their intersections. Within the grid systems, there are settlements (points) situated along a line making use of a numerical axis.

As stated before dating the grids and presenting any dating evidence or defining the reasons for their creation is beyond the scope of this study. And, a detailed study should be conducted to define the relation between civilisations, their settlements and grids, dates of emergence or presence of other grids.

For the invisible grids dating evidence could be initially given on the basis of settlements historically known to belong to certain ancient states or empires. In other words, grid dates are given according to settlements that provide archaeological references of certain civilisations and cultures.

The inclination angle of the vertical lines of each grid to the north can be the evidence that could be used for dating of invisible grids. The other evidence is the number of settlements each grid intersects. The earlier grids have numerous settlements placed in the intersection points whereas most of the later period grids, settlements fewer in number are located on the lines. Settlement of a grid could be founded through migrations or after invasions or concurrence of a region. Strategic importance of some settlements may have been preserved in order to define grid lines or to be placed in intersection points of grids of later periods. The lines are thought to be defining spatial networks and geographies of control of their period. The settlements determined have locations on terrestrial regional passages or on main trade axis.

There may be several reasons for why civilisations would have chosen to space (new) settlements along a regular grid pattern rather than positioning them in locations that are attractive from a practical point of view (i.e. proximity to water, food, natural protection against the elements and foes, etc). During the analysis it is found 
out that these locations are both strategic and attractive resulting from the Anatolian geographical characteristics.

The major reason of grid patterning by settlements must the permission to establish a new settlement for locals of or migrants to this geography and let them become the member of the state or empire affiliated or resettlement purposes. The right to establish a city or resettlement of people was a common exercise in the Hittite period (Atila, 2018:723, Bülbül, 2010:21, Gavaz, 2007:123).

Calculation of time and equinox with trade or agriculture purposes must be another purpose. Grids may be demanded for the calculation of distance, space and time differences for these activities. Locations and distances are thought to have been determined with reference to the central settlement which was also the administrative centre.

It can be established that some types of grid belong to the periods of the Hatti, the Hittites, the Tabal Kingdom and the Persians by virtue of the ancient settlements and mounds which the grid lines pass through.

The research carried out by Towers (2017) on the prehistoric Pueblo natives in Arizona demonstrates that people without a written language or number system were able to use perfect geometry to create complexes of architectural buildings on the land. In the ancient era, in addition to the perfect use of geometry in grids, the grids show signs that Euclidean geometry was used before it was formally described by Euclid. However, it is impossible to make a clear estimate of the date when this kind of geometry was first used to form a grid.

Ancient land measures are found to have been used in determining the dimensions of grid lines. The land measure used by the Hittites was the iku. One iku was equal to 30 ammatu and corresponds to $15 \mathrm{~m}$ (Reyhan, 2018; Dönmez, 2013; Ünal, 2007). Another measuring unit employed by the Hittites was the dana. One dana corresponded to $100 \mathrm{iku}$ and hence to $1,500 \mathrm{~m}$. Hittites used a senary (base-6) number system. According to this systematic 1 ammatu was used for $0.5 \mathrm{~m}$ (Atila, 2018:711). The intervals between the lines in the Hittiteera grids were investigated in multiples of 5 in the senary system. For the Persian period, the ancient Iranian unit of measurement the parasang was used in identifying the grids.

It is very likely that all of the dimensions of the grids were multiples of the length of a human stride or foot, or of the distance which a horse could travel within a day or the equivalent in time. However, it is considered that it will only be possible to draw conclusions on this matter following studies to define the precise location of the settlements. The grids have been drawn partially and so not all of the settlements situated along the lines and at the intersections are situated in the grid. All grid lines or boundaries are ungiven due to the technical limits of the Google Earth programme.

Settlements where the ancient-era grids intersect more than twice have been identified as reference settlements: Maşathöyük, Alacahöyük, Boğazkale, Afyonkarahisar, Aşağıpınarbaşı (Konya), Ereğli (Konya), Mersin, Çamardı (Demirkazık), Çarşı, Güllüdağ, Nevşehir, Karlık
(Ürgüp), Kaman, Bünyan, Kayseri, Sindel höyük, Karatepe, Halep, Idlib, Nizip, Şanlıurfa, Harran, Akçakale, Bozova, Mucur, Akyazı, Erbaa and Erduası.

\subsubsection{Grid D-White Grid}

The dimensions of the Grid D are $15 \mathrm{~km} \times 95 \mathrm{~km}$. (Figure 9). Its origin is Boğazkale. The grid passes through settlements of the early Hittite period. The grid periphery seems to be till mountain rows that define the inner Anatolia. As many as 242 settlements have been identified on the grid lines.

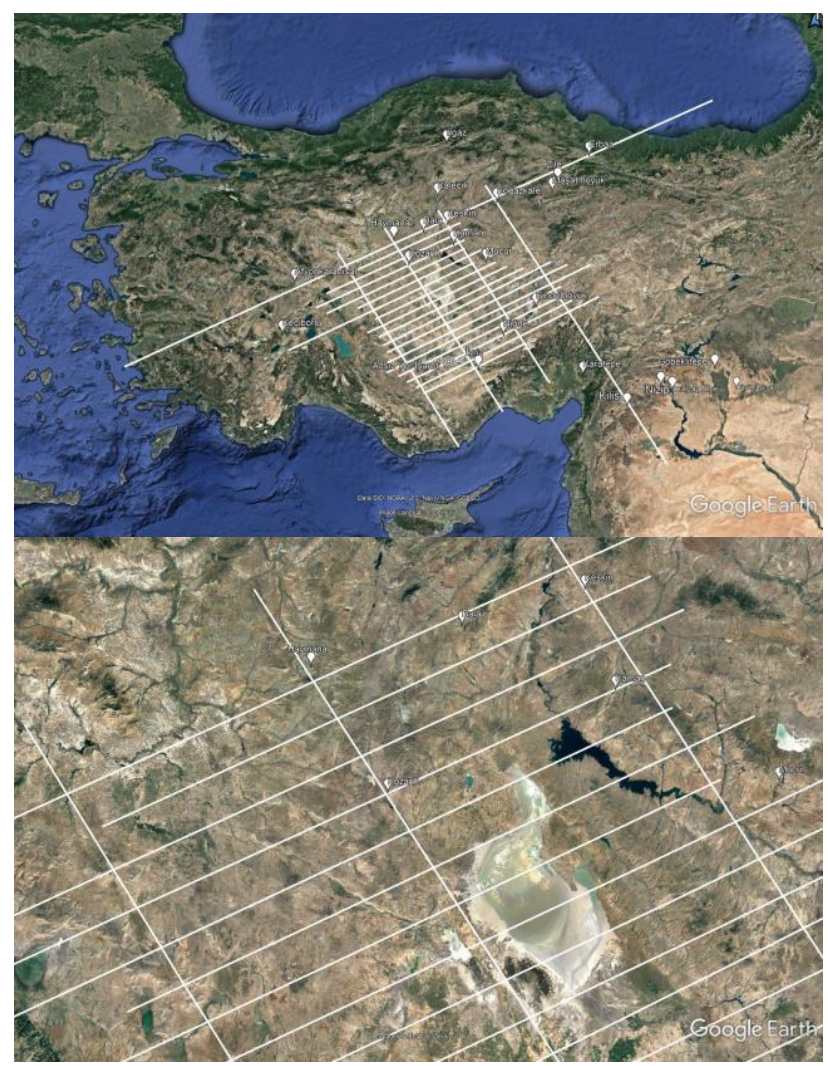

Figure 9. Grid D. Source: Google Earth 2013, Author's Drawing. 2018. a. Grid D [23.11.2013. Eye level $1,216.16 \mathrm{~km}$ ] b. Detail [23.11.2013. Eye level 239.40km]

Grids settlement are: Mut, Yapıntı, Morcalı, Dinlendik, Konya, Kadınhanı, Yunak, Sı ğırcık, Aktaş, Sarıdeğirmen, Haymana, Şerefligökgöz, Kutluhan, Kozanlı, Acıkuyu, Eşmekaya, Ereğli, Biçilganli, Kiledere, Suvermez, Acıgöl, Gözler, Yağmurluarmutlu, Keskin, Yeşilvadi, Değirmenli, Çukurbağ, Hakkıbeyli, Cerenli, Çörten, Yüksekören, Mollaosmanlar, Çiçekli, Salmanköy, Boğazkale, Evci, Gökçe, Kışla, Karabıyık, Poyrazlı, Akın, Akçatepe, Kumköprü, Süleymanlı, Küçüksır, Fatih, Hamidiye, Kuzoluk, Eğlen, Oylumlu, Dowaibeq, Didim, Kapıkırı, Altınova, Alamut, Dualar, Pirlibey, Dörteylül, Gencelli, Bostanyeri, Doğan, Çalçakırlar, Üçkuyu, Belence, Çiğiltepe, Nuh, Taşoluk, Değirmenayvalı, Akkoyunlu, Davulga, Eşrefli, Aydınlı, Tabaklı, Sögülttepe, Karahoca, Keklicek, Küçüksarıkayalar, Azgin yaylası, Çerikli, Kurbağalı, Mehmetbeyli, Alaca, Gökören, Soğucak, Karaşar, Abacı, Avşar, Tosunlar, 
Salkımören, Ortaköy, Eskiçokdeğirmen, Perşembe, Yukarıaliçomak, Güzelcekale, Büyükceceli, Karapınar, Karakışla, Yunak, Yukarısebil, Mahmatlı, Sofular, Çayözü, Himmetuşağı, Büyükabdiuşağı, Dereçine, Kıllar, suluklu, Kozanlı, Karacadağ, Büyükkışla, Küçükdamlacık, Kargınkızıözü, Kaman, Bayındır, İsahocalı, Yalvaç, Hisarardı, Karabulut, Tuzlukçu, Yeşiloba, Savakışla, Savabağbaşı, Demirli, Misafirli, Kuyulusebil, Palazobası, Boztepe, Isparta, Yazısöğüt, Büyükhacılar, Bademli, Eğirdir, Ilgın, Gözlü, Hodoğlu, Cihanbeyli, Çavuşköy, Çıngıl, Sarıyahşi, Bekdik, Beykonak, Çubuk, Kadınhanı, Yapalı, Camili, Kumgöl, Küçükburunağıl, Derbent, Tepeköy, Kurşunlu, Kınık, Taşpınar, Abuuşağı, Karaburç, Kızılağıl, Karakaya, Borukkuyu, Yenikuyu, Ulukışla, Fatmauşağı, Ozancık, Tuzköy, Eskiyaylacık, Karacauşağı, Konya, Ortakonak, Zencirli, Kızören, Eşmekaya, Gültepe, Gözksügüzel, Karakova, Erler, Sakyatan, Yağlıbayat, Bahçesaray, Ürgüp, Fatih, Aksular, Gönen, Erkilet, Hasan Arpa, Burhaniye, Büyüktuzhisar, Sultanhanı, Ihlara, Kavak, Dedemoğlu, Til, Şahinefendi, Sultansazı, Sakarçiftliği, Hacılar, Akdam, Talas, Büyükbürüzgün Fatih, Tahtaköprü, Obruk, Develi, Okçu, Üçhüyükler, Türkmenkarahöyük, Karakapı, Uluören, Çarşı, Bağlama, Alay, Soğanlı, Erciyes Tepe noktası, Kepez, Arıkören, Ereğli, Karapınar, Beyören, Taşbudak, Yaylayolu, İçmece, Sindelhöyük, Cücüm, Çukurağaç, Akarköy, Çoğlu, Bor, Niğde, Çubuklu, Yerköy, Kocahacılı, Epçe, Güzelce, Süvegenlier, Kızık, Adabağ, Sarıtopallı, Özgürler, Taşhan, Eşelik, İmamkullu, Ayvat, Fettahdere, Yıldızlı, Toraman, Başmakçı, İmrahor.

\subsubsection{Grid E-Dark Blue Grid}

The dimensions of Grid E are $25 \mathrm{~km} \times 50 \mathrm{~km}$. The direction of the grid is $30^{\circ}$ towards the East of the current North Pole. A total of 91 settlements have been identified on the grid lines or at their intersections. The origin of the grid is Karatepe (Adana).

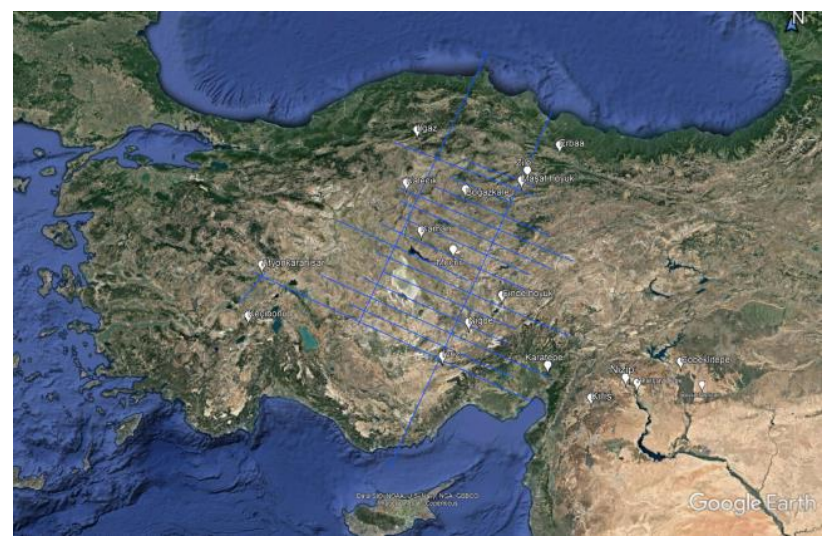

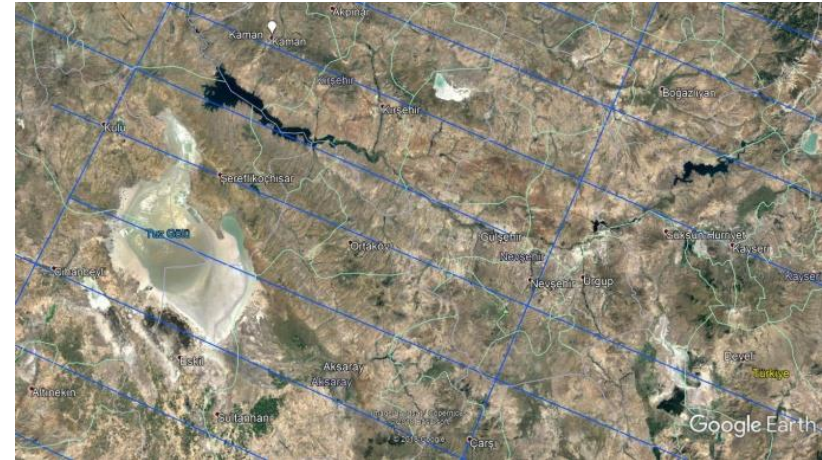

Figure 10. Grid E. Source: Google Earth 2013, Author's Drawing. 2018. a. Grid E [23.11.2013. Eye level $1,216.16 \mathrm{~km}$ ] b. Detail [23.11.2013. Eye level 229.08km]

Settlements situated on grid lines are; Afyonkarahisar, Tavşançalı, Kulu, Karakeçili, Sulakyurt, Ortacalı, Kirazlık (Black Sea), Samsun (Black Sea), Reşadiye, Göre, Çarşı, Altunhisar, Yukarıgöndelen, Acıpınar, Hacımemiş, Göcekler, Aydıncık, Yakapınar, Müminli, Memişli, Kazan hüyüğü, Kesmez, Karapınar, Tömek, Aşağıpınarbaşı, Ilgın, Yaşarlar, Balmahmut, Çaldere, Taşbudak, Koçak, Meydan, Bağtepe, Aladağ, Yavaşl1, İnsuyu, Gölyazı, Büyükçakır, Şereflikoçhisar, Tekir, Sofular, Çuluk, Yassıhüyük, Sazılar, Tatık, Obruk, İlicek, Köşektaş, Kayseri, Talas, Başakpınar Ufuk, Avşarsöğütlü, Kululu, Uzunlu, Çakmak, Ç,çekdağı, Boğazevci, Ulaş, Yeşildere Fatih, Terzili, Hacıuşağı, Başınyayla, Esenli, Karakışla, Sızır, Dendil, Gümüşdibek, Güldibi, Çatmasöğüt, Sorgun, Dişli, Derbent, Boğazkale, Aydoğan, Karakaya, Alacahöyük, İlbeyli, İncesu, Çayhatap, Kireçocağı, Sugıylan, İncik, Ahlatköy, Beşpınar, Cerit, Celikkırı, Aşağısaraylı, Eskiekin, Beşiktepe and Hacılar (Figure 10).

\subsubsection{Grid F (Şanlıurfa Grid) - Orange Grid}

This grid has its origin in Şanlıurfa (or Harran?) and is made up of parallel lines drawn at intervals of $25 \mathrm{~km}$ $(25 \mathrm{~km} \times 25 \mathrm{~km})$ in four directions created at a $30^{\circ}$ angle from today's North towards the North West (Figure 11). The North is thought to have been referenced using İkiztepe, Bafra (Black Sea). The line joining İkiztepe, Şamluurfa and Harran is the first meridian. In all, 54 settlements have been identified on the lines of Grid F or at their points of intersection.

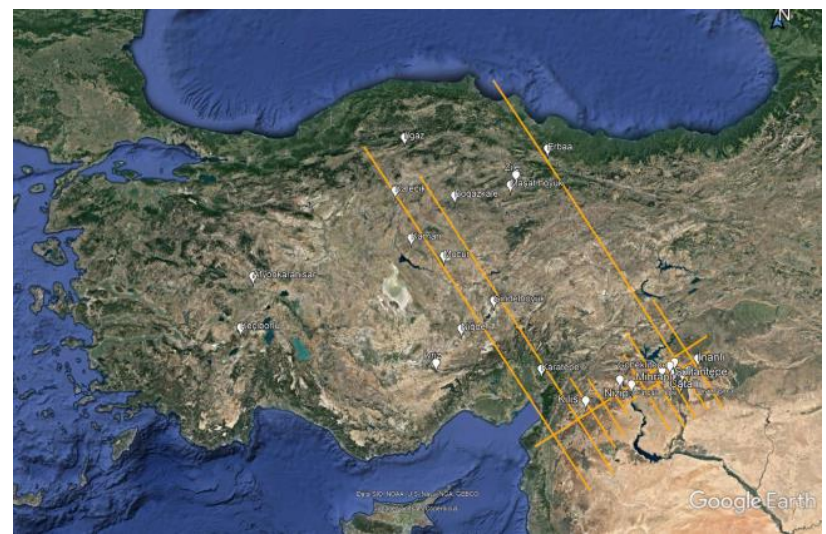




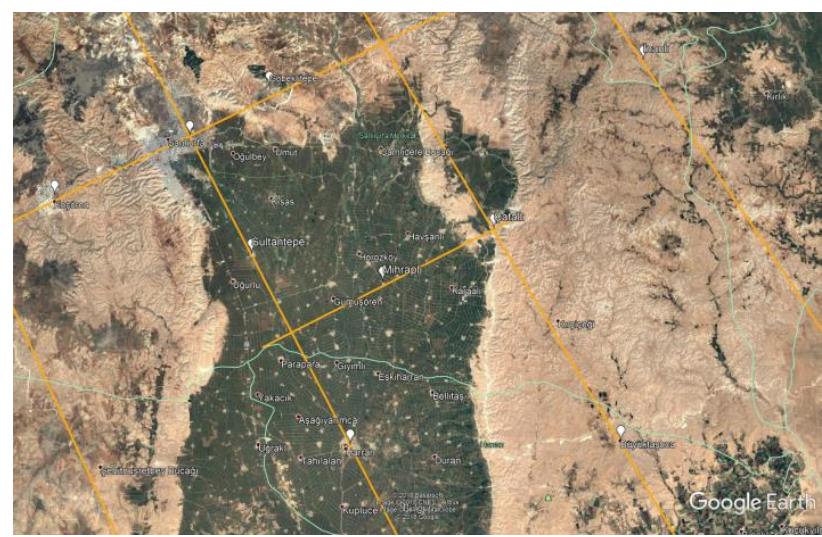

Figure 11. Grid F. Source: Google Earth 2017, Author's Drawing. 2017. a. Grid F [23.11.2013. Eye level 1,216.16km], b. Detail [04.08.2017. Eye level $75.52 \mathrm{~km}$ ]

Grid settlements are: Nevşehir, Çerkeş, Mucur, Bağtepe, Sarıseki, Karapınar, Yeniköy, Düziçi, Merkez, Boğazköprü, Büyükyağlı, Kanlıca, Hacımusalı, Aydıngün, Balkaya, Ilgaz, Pınarbaşı, Güneykent, Sarıbaşak, Yeşilce, Alacalı, İnnaplı, Gümüşgün, Kırıkhan, Münbiç, Ayn el Arab, Çakallı, Doğanşehir, Akpınarbucağı, Akçadağ, Kaynarca, Ilısuluk, Kovalı, Geyraş, Kerim (Black Sea), Doğankaya (Bafra, Black Sea), Karkamış, Harran, İkiztepe, Erbaa, Dilek, İnanlı, Kapıkaya, Üçkuyu (Diyarbakır), Latakya, Idlib, Aleppo, Kırlık, Altınahır, Ortanca, Başbük, Koçören, Buhara and Şanliurfa.

\subsubsection{Grid $G$ - Blue Grid}

The dimensions of Grid $\mathrm{G}$ are $45 \mathrm{~km} \times 95 \mathrm{~km}$. Its origin is Alacahöyük. The grid is oriented $45^{\circ}$ from today's North, towards the North West. The number of settlements identified on the grid lines or at their intersection points is 35. Settlements situated on grid lines are as follows: Idlib, Aleppo, El Bab, Kısas, Çamlıdere bucağı, Beşpınar, Balova, Dedeköy, Daldalık, Rakka, Ayn Al'Arab, Maşathöyük, Doğukesmekaya, Gögeç, Alacahöyük, Al Mahdum, Khan Shaykhun, Nahr al Bared, Ma'saran, Khan Assubul, Kafar Takharım, Qatman, İskenderun, Karataş, Uluyatır, Nizip, Bozova, Akçoban, Nefirtaş, Yığınak, Ağaçkonur, Hilvan, Gözelek, Siverek and Yolçatı (Figure 12).

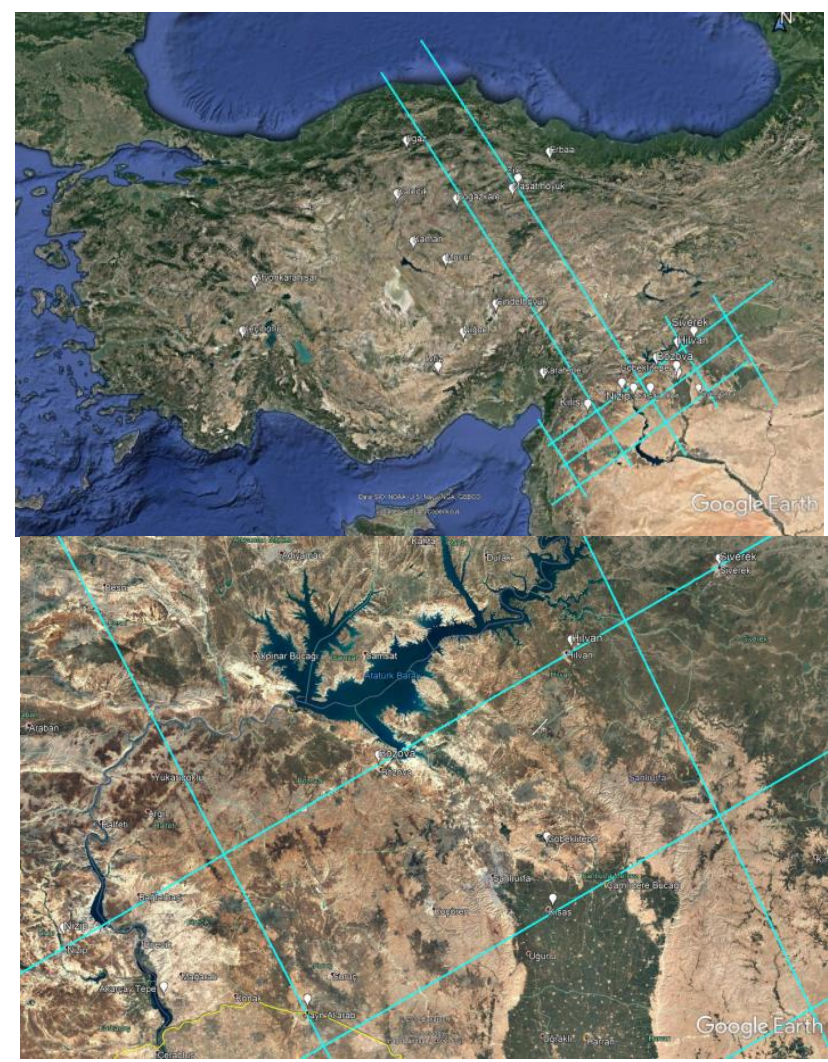

Figure 12. Grid G. Source: Google Earth 2017, Author's Drawing. 2017. a. Grid G [23.11.2013. Eye level $1,216.16 \mathrm{~km}$ ] b. Detail [04.08.2017. Eye level 146.71km]

\subsubsection{Grid H - Light Green Grid}

Another invisible grid belongs to the Tabal Kingdom (See Akçay, 2014). Tabal Kingdom is a Late Hittite city state and is known to have been founded in the south of the Ürgüp region following the destruction of Boğazkale as a result of various attacks. It has been dated to 850-650 BCE. The origin of the grid is the ancient settlement of Göllüdağ. It is situated near the village of Kömürcü in the subdistrict of Gölcük, Niğde (at a distance of $60 \mathrm{~km}$ from the provincial centre and an altitude of $2,172 \mathrm{~m}$ ).

The lines can be read due to Göllüdağ and another, deserted settlement, the name of which is unclear, situated in a saddle-like area at the top of the mountain. It bears indications of some settlements in the Southeast Anatolia region (around Karkamıs). The dimensions are $45 \mathrm{~km} \times 9.40 \mathrm{~km}$ (Figure 13). The orientation of the grid approaches today's North (an angle of about $15^{\circ}$ West of North). The number of settlements identified on the lines of Grid $\mathrm{H}$ or at their points of intersection is 23. Those worth emphasising are: Göllüdağ, Undefined tabal city, Kaleköy, Bahçebaşı, Pusatlı, Bostanlık, Kavakköy, Karlık, Çalış, Saray, Sarıçiçek, Kırankışla, Özlüce, Kaymaklı, Mazı, Yeşilöz, Karlık, Sarıhıdır, Göreme, Nevşehir, Ağıllı, Bağlıca and Harran. 


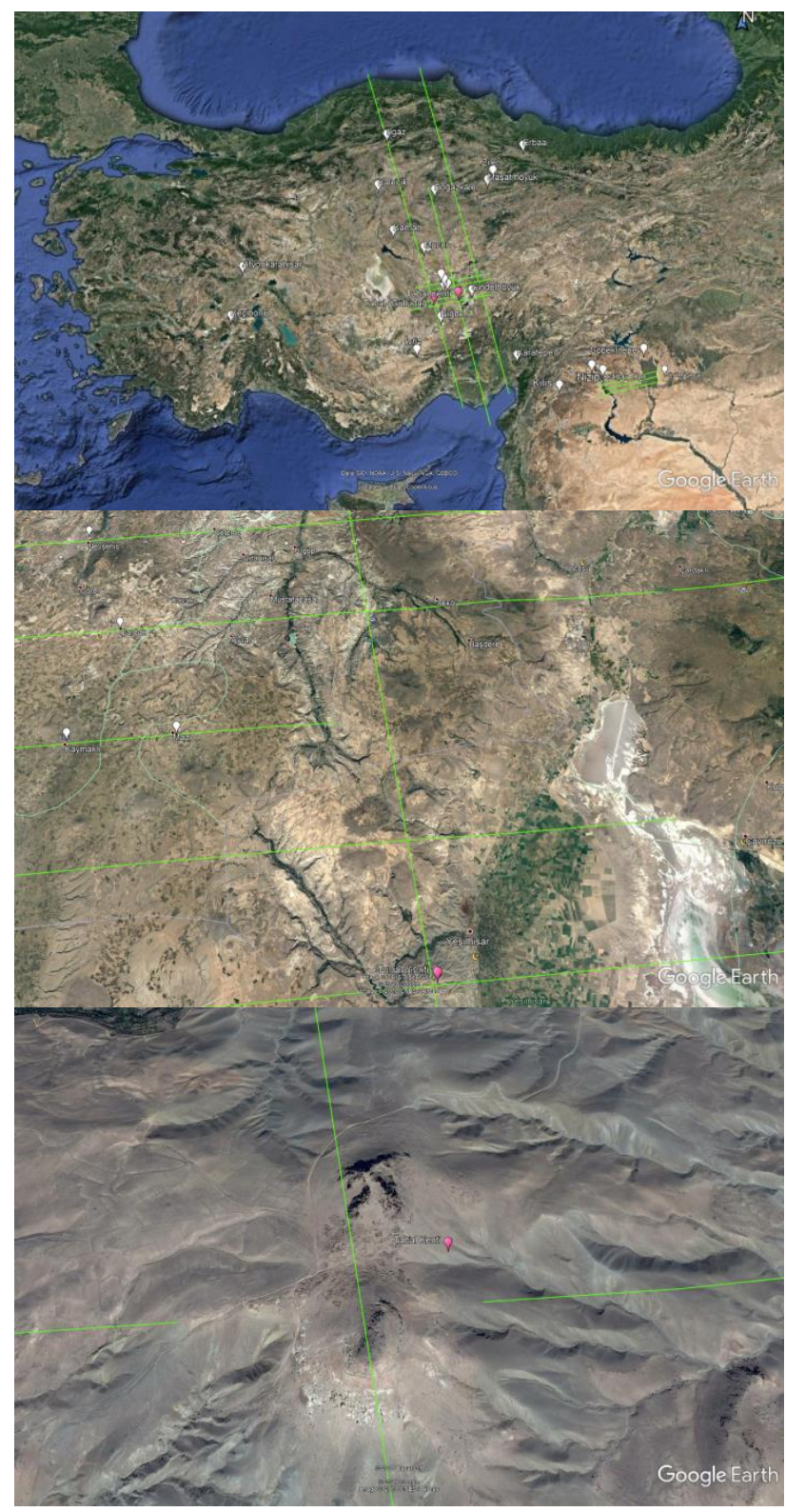

Figure 13. Grid H, Source: Google Earth 2013, Author's Drawing. 2018. a. Grid H [23.11.2013. Eye level $1,216.16 \mathrm{~km}$ b. Detail [04.08.2017. Eye level 44.29km], c. Deserted Tabal City (Name unknown) - Detail [04.08.2017. Eye level 3.07km].

\subsubsection{Grid I - Pink Grid}

The equivalent of the parasang, the unit of measure of distance used in Iran in the ancient era, as used by Herodotus and Xenophon (based on the measures used in Attica), is 5,328m (Bivar, 1985). The schoenus used in Ancient Egypt was equal, according to Herodotus (1859), to 60 stadia or approximately $10,5 \mathrm{~km}$ (Wikipedia, Schoenus and Ancient Egyptian units of measurement, 2018). Fundamentally, one schoenus is twice as long as a parasang $(10,656 \mathrm{~m})$. The use of multiples of the same number in both regions indicates the widespread nature of its use.

One measure of a foot is $29,6 \mathrm{~cm}$ from the big toe to the big toe on the other foot. Multiplying this by 180 yields 5,328 . Dividing the number 5,328 by $26.64 \mathrm{~cm}$, the distance between the two feet, gives us the number 200. It has thus been established that $26.64 \mathrm{~cm}$ is the length of a pace and that a parasang is 200 times this in metres. Meanwhile, five times $5,328 \mathrm{~m}$ makes $26,640 \mathrm{~m}$ $(26,64 \mathrm{~km})$. For these reasons, the distance $26.64 \mathrm{~km}$ was adopted when searching for a grid. The dimensions of Grid I are $26.64 \mathrm{~km} \times 26.64 \mathrm{~km}$. Its point of origin is Persepolis and it is oriented towards the North West. Grid dimensions gives a clue for the knowledge of the round Earth. When the circumference of the Earth $(40,075 \mathrm{~km})$ is divided by $26,64 \mathrm{~km}, 1504$ vertical lines emerges.

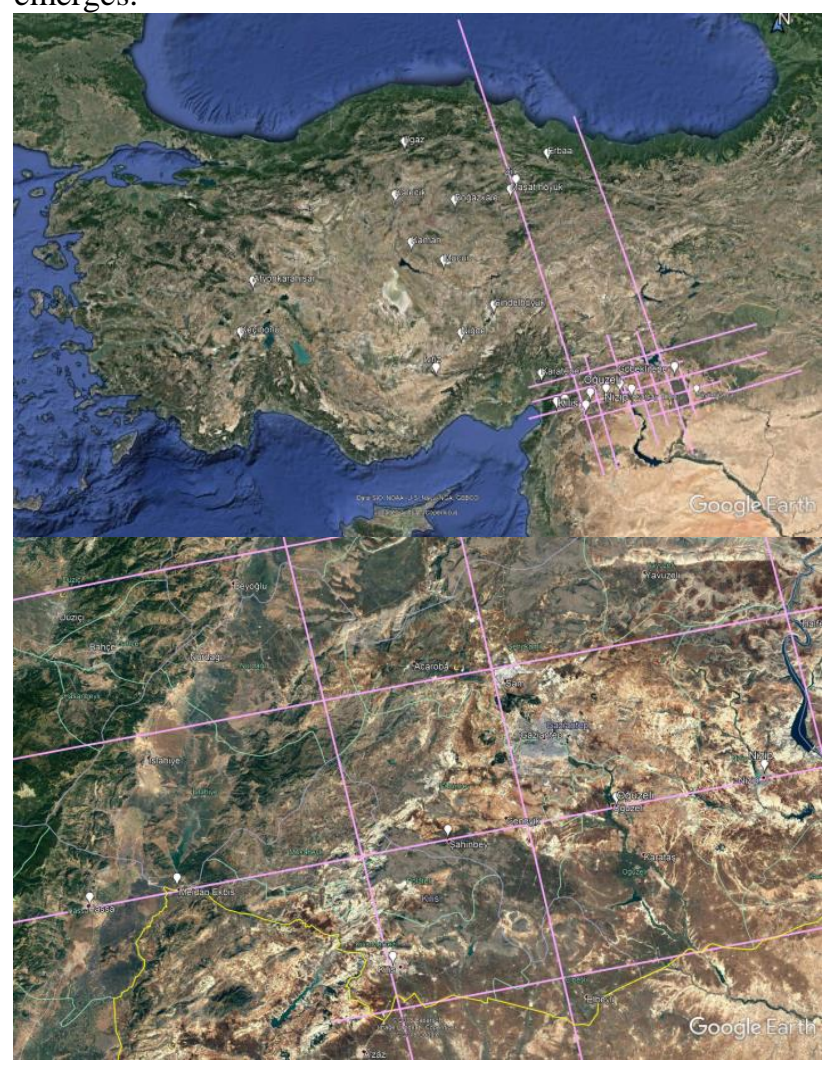

Figure 14. Grid I, the Persian Grid Source: Google Earth 2013, Author's Drawing. 2018. a. Grid I [23.11.2013. Eye level 1,216.16km] b. Detail [04.08.2017. Eye level $75.82 \mathrm{~km}]$.

The number of settlements found on the grid lines or at the intersections are 44: Orhaniye, Atalan, Karacoğlan, Köklüce, Yolveren, Yaylacık, Çakırçeşme, Kadıkent, Gerçek, Soydan, Çiçekliyurt, Dicle, Kozan, Bahçecik, Yasince, Kopuz, Türkmen, Bozova, Kılıçören, Binekli, Erikli, Turunçlu, Kurtkulağı, Narlık, Karatepe, Akpınarbucağı, Siverek, Karpuzlu (Diyarbakır), Hilvan, Keremli, Karaali, Olgunlar, Taylıca, Akçakale, Şanlıurfa, Akçahisar, Çakmak, Bahçeli, Yeşerdi, Çamurlu, Malatya, Zara, Ünye (Black Sea) and Persepolis (Figure 14).

\subsubsection{Grid J-Yellow Grid}

The dimensions of Grid $\mathbf{J}$ are $30 \mathrm{kmx} 50 \mathrm{~km}$. The determinant meridian is Maşathöyük-Karatepe (Adana. Maşathöyük has been determined to be the origin. Fiftyeight settlements have been identified on the grid lines or at their intersections. Grid settlements are: Çarşı, Darboğaz (Ulukışla), Mersin, Büyükdikli, Karahan, 
Beydemir, Ürgüp, Dörtyol, Kozaklı, Karaşehir, Osmaniye, Alacahöyük, Hanönü, Güzelkent, Sinopyarımadası (Burunuçkısmı), Durağan, Kızılca, Esentepe, Çiğdemli, İnevi, Erkilet, Arabidin, Erciyes, İmamoğlu, Zeytinbeli, Kırıkhan, Güzelce, Çaybaşı, Karaözü, Kayseri, Kadışehri, Maşathöyük, Meşeliçiftliği, Saygill, Suluova, Armutlu, Çeltek, Çekalan, Demircideresi, Derebağ, Ovacık, Tepeköy, Mülayim, Derbent, Yassibel, Atabey, Keçiborlu, Akören, Hacımemiş, Düziçi, Bozkır, Seydişehir, Ulukışla, Karatepe, Dereköy, Reyhanlı, Fatmalı and Karaman (Figure 15).

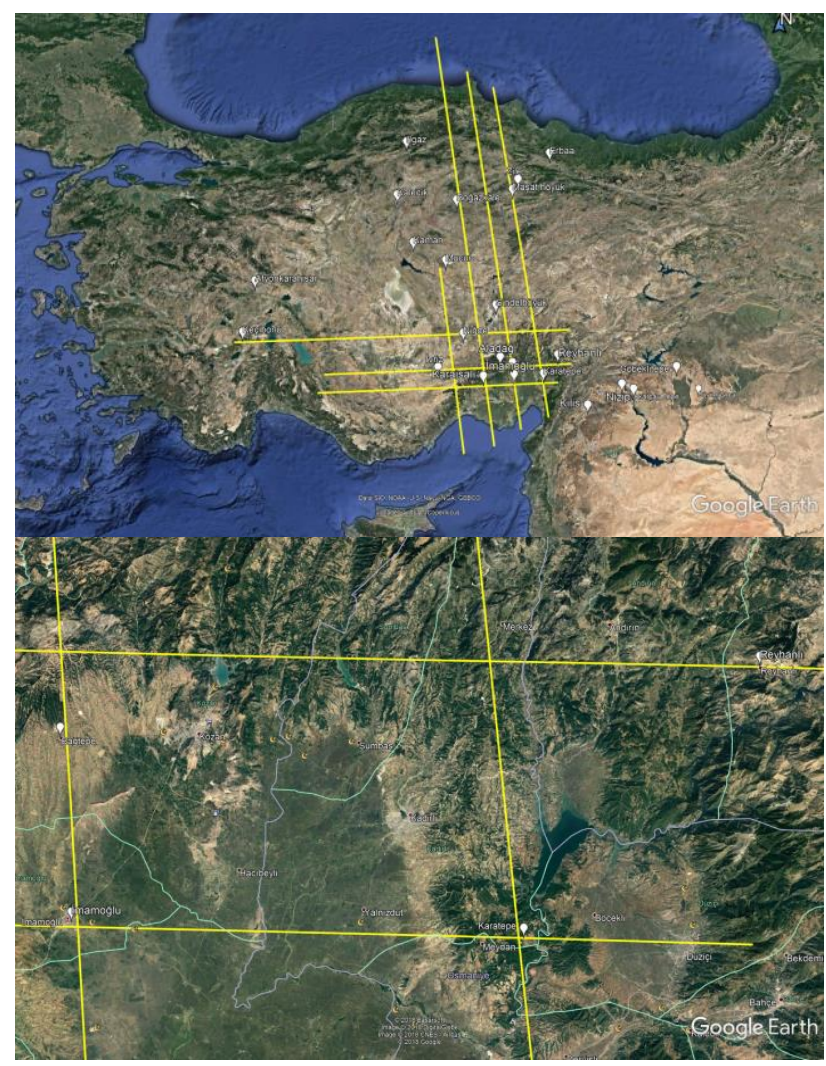

Figure 15. Grid J. Source: Google Earth 2013, Author's Drawing. 2018. a. Grid J [23.11.2013. Eye level $1,216.16 \mathrm{~km}]$ b. Detail [04.08.2017. Eye level $80.22 \mathrm{~km}]$

\section{Conclusion}

Spatial planning needs to be carried out and land arrangements must be made in order to measure distance and time, apportion of land, prevent social chaos and structure the law (Eren, 2018a). Cartography is the basis of spatial planning. Grids are an instrument used in the conduct of cartography - a way of measuring the earth's surface according to a certain spatial reference point and principle. A grid makes use of natural numbers and/or decimals to calculate areas of land, amounts of crops, gradients, distances and time.

A grid is also a numerical axis (line) system. It divides the whole or a part of the surface of the earth systematically into squares or rectangles using parallel lines drawn at oblique or right angles. The grid pattern is the result of this division. Every grid system has its origin and hence a different north orientation. The direction of north and the systems of grids can be assumed to have changed with the development of human spatial awareness and technical and technological progress.

The grids of ancient Anatolia constitute spatial inputs which make it possible to measure and understand human settlements, the land pattern and the systematics of life. By using the subdivisions of land and locations of settlements to identify grids based on ancient measuring units, it is thought that it will be possible to describe the spatial relationships and networks of the settlements under the control of civilisations of the ancient era, and to determine the borders of the civilisations at given periods. The nature of these grids points not only to a concern to subdivide land properly and fairly within a given area or region, but also to the social acceptance of a certain manner of locating accommodation areas and dividing up the land with agricultural purposes.

While invisible grids described in this paper are based on the same systems of coordinates that are in use today, they are also systems of geographical coordinates which reflect the different perceptions of the world and the universe of the period in which they were conceived. The geography a civilisation controls, the understanding of the earth and the universe can be understood with the grid peripheries. All of the grids are inertial local systems used in line with the perception of a flat earth. It is thought that in the Persian era there is the knowledge of a round earth.

Each grid differs from the others with respect to their starting points and borders, the directions of their axes (orientations) and their dimensions. The grids can be dated to given periods on the basis of the ancient civilisation measuring units and number systems used. It is considered likely that other, different grids exist as well, which are not included in this paper.

Settlement locations in accordance with a grid system should be evaluated as an input to the spatial planning approach of the ancient era. The grids indicate the mastery of a wide geographical area and supply information about the spatial knowledge of the period when the settlements were created. The grids are thought to have been constructed, the settlements to have been located and the distances between them measured and projected, with the aid of a knowledge of astrology. However, there is a need for more advanced studies to establish this relationship.

\section{Acknowledgements}

I would like to thank Mehmet Bildiş and Bernard Kennedy for their contributions.

\section{References}

Akçay, A. (2014). "Tabal Ülkesinin Tarihsel Süreci Üzerine Bir Değerlendirme”. Tarih İncelemeleri Dergisi, XXIX / 1, 37-58 ["An Evaluation of the History of the Tabal State". Journal of Historical Investigations, XXIX / 1, 2014, 37-58]

Arimura, M., Balkan-Atl1, N., Borrell, F., Bucak, E., Cruells, W., Duru, G., Erim-Özdoğan, A., Ibáñez, J.J., 
Maede, O., Miyake, Y., Molist, M. and Özbaşaran, M., 2000. "Akarçay Tepe Kazısı, 1999" ["Akarçay Tepe Excavation, 1999"'], in Tuna N., Öztürk J. and Velioğlu J. (Eds.). Ilısu ve Kargamış Baraj Gölleri Altında Kalacak Arkeolojik Kültür Varlıklarını Kurtarma Projesi 1999 Yılı Çalışmaları [Salvage Project of the Archaeological Heritage of the Ilisu and Carchemish Dam Reservoirs Activities in 1999], ODTÜ [Middle East Technical University]-TAÇDAM, Ankara: 181-190.

Atila, N. (2018). "Hititlerde Kent ve Kent Kimliği Üzerine Bir değerlendirme". [Assesment on Hittite City Structure], Journal of History School (JOHS), October 2018. Year 11, Issue XXVI, pp. 698-732.

Bivar, A. D. H. (1985). "Achaemenid Coins, Weights and Measures", in Gershevich, Ilya, The Cambridge history of Iran: The Median and Achamenian Periods, vol. 2, Cambridge University Press, pp. 610639, ISBN 0-521-20091-1.

Bogaard, A. Filipović, D., Fairbairn, A., Green, L., Stroud, E., Fuller, D. and Charles, M. (2017). "Agricultural innovation and resilience in a long-lived early farming community: the 1,500-year sequence at Neolithic to early Chalcolithic Çatalhöyük, Central Anatolia”, Anatolian Studies 67 (2017): 1-28

Bozbay, H. (2009). Neolitik Dönem Akarçay Tepe Yerleşmesinde Küçük Buluntular Işığında Zanaat Ürünleri. İstanbul Üniversitesi. Sosyal Bilimler Enstitüsü. Arkeoloji Ana bilim Dalı. (Basılmamış) Yüksek Lisans Tezi. [Craft Products in the Light of Small Findings in the Neolithic Settlement of Akarçay Tepe. Istanbul University Institute of Social Sciences. Archaeology Department. (Unpublished) Master Thesis.]

Bülbül, C. (2010). "İdrimi Zamanında Alalı Krallığı", History Studies. Vol 2/2. pp.15-27.

Bülbül, P. (2017). "Eski Anadolu'da Tarım Faaliyetleri”, Tarihin Peşinde. 4. Uluslararası Tarih ve Sosyal Araştırmalar Dergisi. Y1l 2017. Sayı 17. 268-282. ["Agricultural Activities in Old Anatolia", In Pursuit of History. Fourth International Historical and Social Research Journal. Year 2017. No. 17. 268-282]

Childe, V. G., 1971. Doğunun Prehistoryası [New Light on the Most Ancient East, translated by Şevket Aziz Kansu]. Türk Tarih Kurumu Basımevi [Turkish Historical Society Publications], Ankara, 2nd Edition.

Childe, V. G. (1974). Tarihte Neler Oldu [What Happened in History? Translated by Mete Tunçay and Alaeddin Şenel]. Alan Publishing. İstanbul.

Dönmez, S. (2013). "Hitit Döneminde Değişim Araçları ve Ölçü Birimleri" ["Means of Exchange and Measurement Units in the Hittite Era"]. International Journal of Social Science. Vol. 6 issue 8, 813-832.
Eren. Ş.G. (2018a). Akarçay Tepe Technical Report. DOI: $10.13140 /$ RG.2.236381.56806.

Eren. Ş.G. (2018b). “Ancient Smart Cadastrate: Akarçay Tepe Cadastral Map”. (09.05.2018). 26th FIG Congress. Istanbul. Embracing our smart world where the continents connect: enhancing the geospatial maturity of societies. 06-11 May 2018.

Herodot; Murray, John, trans., ed. (1859). The History of Herodotus: A New English Version, Oxford Univ. Press.

Memiş, E. (2016). Tarihi Coğrafyaya Giriş. Ekin. 3. Bask1. [An Introduction to Historical Geography. Ekin Publications. Third Edition]

Özbaşaran, M., Molist, M. (2007). “Akarçay Tepe, Orta Furat'ta Neolitik Döneme Ait Yeni Bir Yerleşme" in Mehmet Özdoğan, Nezih Başgelen (Eds). Anadolu'da Uygarlığın Doğuşu ve Avrupa'ya Yayılımı. Türkiye'de Neolitik Dönem: Yeni Kazılar, Yeni Bulgular, Arkeoloji ve Sanat Yayınları, İstanbul: 179-187. [“Akarçay Tepe, A New Neolithic Era Settlement in the Middle Euphrates" in Mehmet Özdoğan, Nezih Başgelen (Eds). The Birth of Civilisation in Anatolia and its Expansion to Europe. The Neolithic Era in Anatolia: New Excavations, New Findings, Archaeology and Art Publications, Istanbul: 179-187]

Özbaşaran, M. (2008). “9000 Y1llı Bezemeli Kireçtaşları" in Euergetes, Prof. Dr. Haluk Abbasoğu'na 65. Yaş Armağanı, Vol. II, Suna-İnan Kıraç Akdeniz Medeniyetleri Araştırma Enstitüsü: 833-39. [“9,000 YearOld Marked Limestones" in Euegertes, In Honour of Prof. Haluk Abbasoğu in his $65^{\text {th }}$ Year,Vol. II, Suna-İnan Kıraç, Mediterranean Civilisations Research Institute: 833-39]

Reyhan, E. (2010). "Hititlerde Gündelik Hayata Dair İktisadi İlişkiler”, Ankara Üniversitesi Dil ve TarihCoğrafya Fakültesi Tarih Bölümü Tarih Araştırmaları Dergisi, 47 /29, 65-82. ["Economic Relations in Daily Life among the Hittites", Ankara University Faculty of Languages, History and Geography Department of History Journal of Historical Research, No: 47 Vol. 29, 65-82.]

Sir-Gavaz, Ö. (2007). I. Šuppiluliuma Döneminde Suriye ve Mezopotamya ile İlişkiler [Relations between Syria and Mesopotamia in the period of Šuppilulium I] (Yayınlanmamış Yüksek Lisans Tezi) [Master Thesis (Unpublished).] Ankara.

Şerbetçi, M. (1999). Türk Haritacılık Tarihi. (1895-1995). TMMOB Harita ve Kadastro Mühendisleri Odası. [History of Turkish Cartography (1895-1995). Union of Chambers of Architects and Engineers of Turkey Chamber of Map and Cadastre Engineers.] Istanbul. 
Towers, S. (2017). Advanced geometrical constructs in a Pueblo ceremonial site, c 1200CE. Journal of Archaeological Science: Reports, 12:1DOI:10.1016 /j.jasrep.2017.01.009

Ünal, A. (2007). Hititçe Çok Dilli El Sözlüğü I-II. [Hittite Multilingual Pocket Dictionary I-II.] Hamburg.

Üstün, A. (1996). Datum Dönüşümleri. Yıldız Teknik Üniversitesi. Yüksek Lisans Tezi (Basılmamış). [Datum Transformations. Yıldiz Technical University. Master Thesis (Unpublished).] İstanbul.

Internet resources:

- http://acikarsiv.ankara.edu.tr/browse/31888/haritavegr afiknotlari.pdf Harita ve Grafik Analizler. Ankara Üniversitesi Açık Erişim Sistemi Ders Notları. (Onur Çalışkan, 2017) [Maps and Graphic Analyses. Ankara University Open Access System Lecture Notes. (Onur Çalışkan, 2017] Accessed: 05.06.2017.

- Graftek. Türkiye'de kullanılan Koordinat Sistemleri [Systems of Coordinates used in Turkey]. Accessed 25.09.2018.

- Schmidt, K. 08.07.2014. “What is Göbeklitepe?” TED

Conference.

- Mark, J.J. Fertile Crescent. Ancient History Encyclopedia. 28.03.2018.

- https://eodev.com/gorev/57725810.09.2018.

- https://en.wikipedia.org/wiki/Parasang10.09.2018.

- https://en.wikipedia.org/wiki/Schoenus10.09.2018.

- https://en.wikipedia.org/wiki/Ancient_Egyptian_units _of_measurement10.09.2018. 